\title{
PEMANFAATAN TEKNOLOGI DALAM PEMASARAN GULA MERAH PADA KELOMPOK USAHA PENGOLAH "GULMER"
}

Winarto Ramlan ${ }^{1}$, Ramadhani Chaniago ${ }^{2}$ Yusuf Ayuba $^{3}$

${ }^{1,2}$ Afiliasi/Institusi (Fakultas Pertanian Univeristas Muhammadiyah Luwuk Banggai)

${ }^{3}$ Afiliasi/Institusi (Fakultas Teknik Univeristas Muhammadiyah Luwuk Banggai)

E-mail: winabugar@gmail.com

\section{Article History:}

Received: 31-07-2021

Revised: 19-08-2021

Accepted: 11-09-2021

Keywords: Produksi Gula Merah, diversifikasi produk, media sosial.

\begin{abstract}
Desa Saluan adalah desa yang sebagian masyarakatnya mengolah air nira menjadi gula merah. Pembuatan gula merah ini sangat potensial untuk dikembangkan. Hal ini dikarenakan pengolahannya cukup sederhana serta bahan baku untuk pembuatan gula merah cukup banyak tersedia disekitar lingkungan masyarakat. Tujuan dari kegiatan ini agar kelompok mitra dapat meningkatkan pengetahuan, keterampilan, dan penguasaan Teknologi Tepat Guna serta dapat memanfaatkan Teknologi dalam pemasaran produk. Adapun metode yang digunakan dalam kegiatan pengabdian ini dengan pendekatan Metode Participatory Rural Appraisal (PRA), Metode Participatory Tecnology Development Metode Community development. Produk olahan masih dalam bentuk gula cetak menggunakan tempurung kelapa setengah lingkaran, belum ada olahan bentuk lain seperti bentuk gula semut. Pengemasan produk gula merah hanya dibungkus plastik gula tipis. Penjualan produk dilakukan dengan menawarkan langsung ke pasar, belum memanfaatkan aplikasi media sosial. Hasil kegiatan berhasil memberikan pengetahuan dan pemahaman tentang budidaya pohon aren, diversifikasi produk olahan dan penggunaan handpone sebagai sarana dalam mempromosikan produk gula merah.
\end{abstract}

\section{Pendahuluan}

Desa Saluan adalah salah satu desa yang ada di Kecamatan Moilong Kabupaten Banggai. Desa ini memiliki luas wilayah hanya $3,85 \mathrm{~km}^{2}$ atau $1,74 \%$ dari luas Kecamatan Moilong. Pada tahun 2019 penduduk Desa Saluan sebanyak 435 jiwa atau kepadatan penduduknya 68, 54 jiwa/ $\mathrm{km}^{2}$. Penduduk yang berjenis kelamin laki-laki sebanyak 215 jiwa dan berjenis kelamin perempuan sebanyak 220 jiwa (Badan Pusat Statistik 2020). Secara topografi $100 \%$ dataran dan ketinggian tempat dari permukaan laut sekitar $7 \mathrm{~m} \mathrm{dpl}$. Desa Saluan memiliki jarak 2 km ke ibu kota kecamatan (Desa Moilong) serta memiliki jarak 92 km ke ibu kota Kabupaten (Luwuk), Desa Saluan termasuk pada desa swakarya dari tahun 2015-2019. Desa Swakarya, yang berarti bahwa Desa sudah dapat mengelola atau mengatur pemerintah sendiri dan kebutuhan pangan sudah terpenuhi dengan cara pertanian (Zainudin 2016). 
Sebagian masyarakat Desa Saluan adalah masyarakat yang mengolah air nira menjadi gula merah. Salah satu anggota kelompok telah melakukan pengolahan gula merah dari tahun 1974 atau 46 tahun, pengumpulan air nira untuk dijadikan gula merah dilakukan selama 2 hari sebanyak 20-40 Liter dan dapat menghasilkan 65 biji gula merah. Pembuatan gula merah ini sangat potensial untuk dikembangkan. Hal ini dikarenakan pengolahannya cukup sederhana serta bahan baku untuk pembuatan gula merah tersedia disekitar lingkungan masyarakat.

Produk gula merah merupakan salah satu produk olahan komoditi perkebunan yang banyak dimanfaatkan oleh masyarakat baik di Desa Saluan maupun masyarakat di wilayah lainnya untuk memenuhi kebutuhan sehari-hari baik, untuk membantu ekonomi keluarga, serta membantu ekonomi masyarakat agar menjadi sejahtera. Hal ini menunjukan bahwa Desa Saluan berpotensi dalam mengembangkan pengolahan air nira menjadi gula merah. Hanya saja, kenyataannya dalam pengolahannya belum terkelola dengan baik, karena masih menggunakan alat produksi yang masih sederhana, sehingga dalam memproduksi gula merah masih terbatas. Belum lagi setelah diproduksi, pengemasannya juga masih menggunakan kemasan yang sederhana dan kurang menarik, ditambah lagi cara memasarkan masih tergolong konvesional yaitu menitip ke kios-kios atau toko-toko disekitar lokasi dan pasar induk. Menyikapi hal tersebut, maka perlu adanya perhatian dan dukungan dari semua pihak termasuk pemerintah daerah dalam menunjang pengembangan sistem pengolahan gula merah secara kontinyu dan sistematis melalui pembinaan yang lebih intensif (Hubeis, 2009 dalam (Rahim 2012).

Kelompok pengolah gula merah Desa Saluan berjumlah 5 orang yang diketuai oleh ibu Asma Dalia. Hampir 90\% pengolah gula merah masih menggunakan alat tradisional dan tergolong masih sangat sederhana dapat dilihat pada gambar 2A. Kelompok usaha ini dalam proses produksi mengolah air nira menjadi gula merah harus menyewa 1 hamparan lahan milik orang lain, yang didalamnya terdapat hanya 7 pohon aren yang dahulunya terdapat 14 pohom aren dikarenakan 7 dari 14 pohon tersebut sudah tidak berproduksi air nira. Dari 7 pohon aren tersebut dapat menghasilkan 20 - 40 Liter air nira. Bila penampungan air nira dilakukan dari pagi hingga sore maka dapat dihasilkan 20 liter air nira. Sedangkan bila ditampung dari sore hingga siang hari maka akan menghasilkan 40 liter air nira. Perbedaan hasil tampungan air nira tersebut disebakan oleh lamanya penampungan, semakin lama dilakukan penampungan maka akan menghasilkan air nira yang lebih banyak. 
Dalam proses penampungan air nira aren, kegiatan yang dilakukan adalah memberi kulit kayu yang biasa disebut kulit kayu buli menurut bahasa setempat. Kulit kayu buli tersebut dimasukkan kedalam wadah atau jerigen yang digunakan untuk menampung air nira aren. Menurut penuturan pengolah gula merah, bahwa penggunaan kulit kayu buli tersebut dapat mengurangi atau menghilangkan rasa asam pada air nira aren tersebut. Kulit kayu buli diduga mirip dengan Akar kayu bayur (Pterospermum sp.) yang juga berfungsi dalam fermentasi nira aren. Seperti hasil penelitian bahwa akar kayu bayur yang ditambahkan pada nira aren berfungsi sebagai pengawet tuak sehingga menyebabkan kadar alkohol hasil fermentasi nira aren bertahan lebih lama pada konsentrasi 4\% selama 64 jam serta memperlambat fermentasi alkohol menjadi asam asetat (Mentari, Djangi, and Sudding 2017).

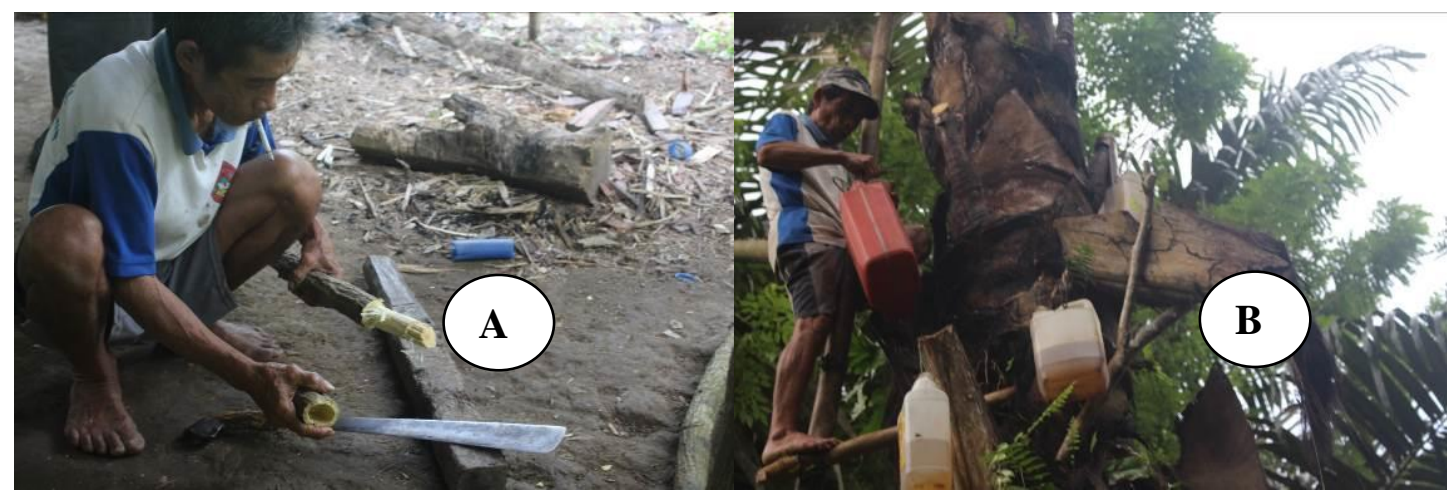

Gambar 1. A. Penggunaan Kulit Kayu Buli dan B. Pengambilan Nira Aren

Kelompok pengolah gula merah berharap usaha produktifnya berkembang menjadi besar meskipun berhadapan dengan banyak permasalahan yang timbul, terutama bidang produksi dan pemasaran. Profile usaha pengolah gula merah disajikan pada Gambar 2 sebagai berikut : 
Tempat dan Alat Pengolah Gula Merah
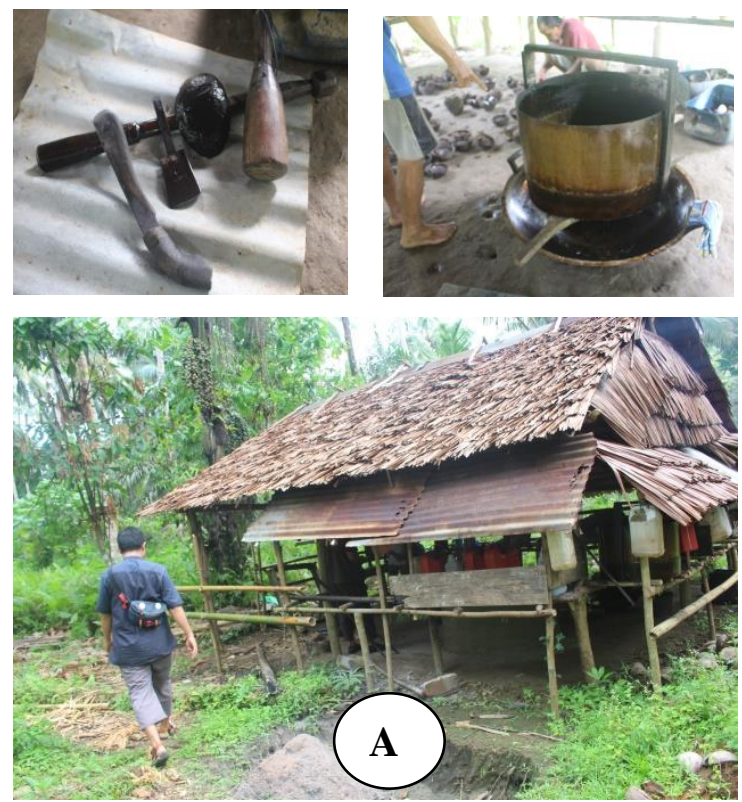

Pencetakan

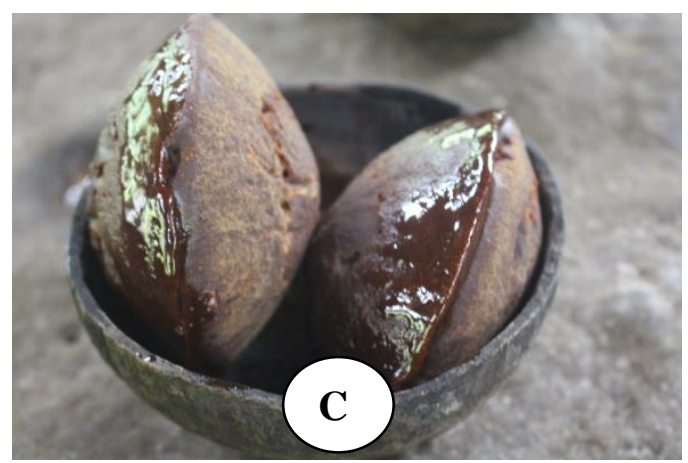

Alat Cetak Gula merah
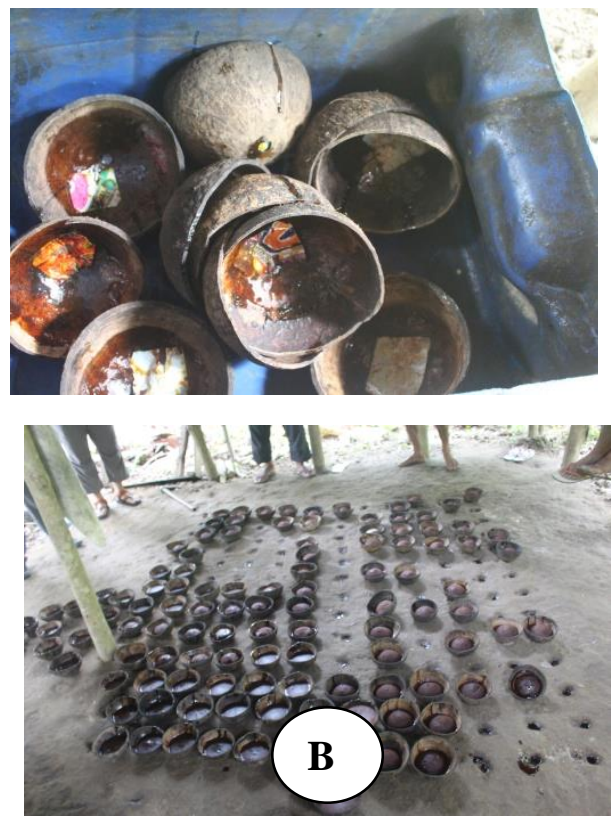

Kemasan Produk Gula merah

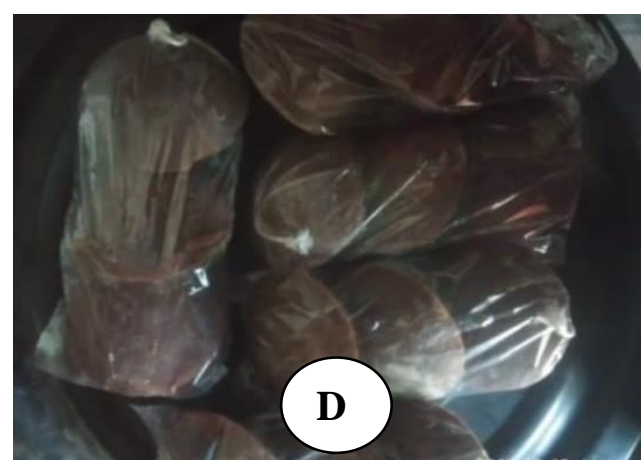

Gambar 2. Profil Usaha Pengolah Gula Merah Desa Saluan

Dari gambar 1. Dapat kita lihat bahwa tempat pembuatan gula merah masih beralaskan tanah, dan diatas tanah tersebut juga dijadikan alas pencetakan gula merah dengan menggunakan tempurung sehingga produk gula merah yang dihasilkan tidak higienis. Selain itu, alat-alat yang digunakan masih sangat sederhana dan terkesan telah usang seperti : wadah penampung air nira, wajan, sendok pengaduk, alat penyaring dan alat cetakan gula merah sehingga dapat mempengaruhi dari kualitas produk dan kuantitas produk sebab volume dan ukuran dari produk gula merah tidak seragam. Dengan adanya volume dan ukuran gula merah yang tidak seragam, maka tidak dapat diketahui berat gula merah dalam 1 biji bahkan perbungkusnya. Kemasannya pula masih menggunakan kemasan konvensional yaitu dengan 
menggunakan plastik yang biasa digunakan sebagai pembungkus gula pasir, sehingga kemasan tersebut dinilai belum menarik bagi pasar moderen. Dengan masih menggunakan kemasan plastik tersebut maka tidak dapat dijual pada pasar-pasar maderen/swalayan atau minimarket yang sudah banyak beredar di Kabupaten Banggai.

Dalam melakukan proses produksi dengan hasil penampungan nira aren sebanyak 1020 liter dapat menghasilkan gula merah sebanyak 60 kepingan atau sebanyak 20 bungkus dalam 1 bungkus isinya ada 3 biji gula merah dapat dilihat pada gambar 2D. Setiap tanaman Aren memiliki waktu optimum sadap selama 3 tahun dan selanjutnya tetap dapat disadap. Hasil niranya antara 300-400 liter per musim (3-4 bulan) atau sekitar 900-1600 liter nira per pohon per tahun. Dalam sehari dapat dilakukan penyadapan sebanyak dua kali (pada pagi dan sore hari), serta menghasilkan 3-10 liter nira per pohon per tiap penyadapan (Goutara 1975)

Pemasaran dari produk gula merah Desa Saluan masih sangat terbatas pada daerah sekitar Kecamatan Moilong atau Kecamatan tetangga yaitu Kecamatan Toili. Penjualannya dilakukan dengan cara menitipkan gula merahnya dikios-kios disekitar Desa Saluan atau dititip ke penjual dipasar serta masih sangat mengharapkan dari pesanan para pelanggan yang datang disetiap pekan atau 2 pekannya. Jadi, kelompok usaha ini mendapatkan pemasukan dari hasil penjualan gula merah disetiap pekan atau 2 pekannya. Melalui program PKM, kelompok mitra dapat meningkatkan pengetahuan, keterampilan, dan penguasaan Teknologi Tepat Guna serta dapat memanfaatkan Teknologi Informasi dalam memasarkan produk gula merahnya kepada konsumen lewat media sosial.

\section{Metode}

Dalam kegiatan sosialisasi Program PKM, metode yang dikembangkan dalam program PKM adalah:

1. Metode Participatory Rural Appraisal (PRA) adalah suatu metode pendekatan dalam proses pemberdayaan dan peningkatan partisipasi masyarakat, yang tekanannya pada keterlibatan masyarakat dalam keseluruhan kegiatan pembangunan. Keterlibatan masyarakat dalam keseluruhan kegiatan tersebut dimulai dari perencanaan, pelaksanaan dan evaluasi program kegiatan. Participatory Rural Appraisal (PRA) dianggap sebagai salah satu pendekatan yang populer dan efektif untuk mengumpulkan informasi di daerah pedesaan (Cavestro 2003) 
2. Metode Participatory Tecnology Development adalah metode yang memanfaatkan teknologi tepat guna yang berbasis pada ilmu pengetahuan dan kearifan budaya lokal (Astuti and Rodiyah, n.d.).

3. Metode Community development adalah metode pendekatan yang melibatkan masyarakat secara langsung sebagai subyek dan obyek pelaksanaan kegiatan pengabdian kepada masyarakat. Community Development menurut (Netting,Kettner,dan McMurty dalam (Suharto 2009)) merupakan salah satu metode atau pendekatan inti yang menunjukkan keunikan pekerjaan sosial dan membedakan profesi ini dengan profesi kemampuan lainnya. Banyak disiplin mengklaim memiliki keahlian dalam bekerja dengan individu, keluarga, dan kelompok. Namun, hanya sedikit profesi yang memfokuskan pada keberfungsian klien dalam konteks organisasi,masyarakat dan kebijakanm salah satunya adalah pekerjaan sosial.

\section{Teknis Pelaksanaan Kegiatan}

Secara teknis, pelaksanaan kegiatan PKM kelompok pengolah aren Desa Saluan adalah sebagai berikut :

1. Persiapan. Pada tahap persiapan ini dilakukan untuk menginventarisasi kondisi dan keadaan serta kebutuhan dari masyarakat khususnya kelompok pengolah gula merah yang dijadikan kelompok binaan, sehingga kegiatan yang dilakukan dapat memberikan solusi bagi permasalahan mitra. Selain itu di tahap awal ini juga akan dilakukan sosialisasi program secara lebih luas.

2. Pelaksanaan kegiatan. Pelaksanaan kegiatan meliputi kegiatan penguatan produksi melalui penataan dan perbaikan peralatan penunjang (wajan, sendok pengaduk, wadah penampung air nira dan alat penyaring), penyediaan alat cetak produksi, penyediaan meja produksi, dan perbaikan tungku pembakaran yang merupakan kegiatan penambahan fasilitas produksi kelompok, kegiatan penguatan kelembagaan dan kegiatan pengembangan SDM kelompok pengolah gula merah. Pelatihan, workshop dan pendampingan akan dilakukan untuk meningkatkan pengetahuan dan kemampuan kelompok pengolah gula merah sehingga usaha yang dikelola dapat berkembang dan berkelanjutan.

3. Evaluasi dan monitoring kegiatan. Kegiatan evaluasi dan monitoring dilakukan secara periodik dengan melibatkan anggota pelaksana dan tokoh masyarakat desa dan bapak kepala Desa Saluan dan Beberapa aparatnya. Evaluasi akan dilaksanakan secara 
keseluruhan untuk mengetahui derajat keberhasilan kegiatan berdasarkan target yang telah ditetapkan.

Tabel 1. Kegiatan yang Dilaksanakan

Kelompok Pengolah Gula Merah Desa Saluan

\begin{tabular}{|c|c|}
\hline & $\begin{array}{l}\text { Pengembangan cetakan gula merah yang bervariasi dan lebih menarik serta } \\
\text { difersifikasi gula merah seperti gula semut, gula merah cair ( } \text { sirup aren). }\end{array}$ \\
\hline Manaje & $\begin{array}{l}\text { 1. Pelatihan pemanfaatan teknologi informasi melalui telepon genggam } \\
\text { (handpone) dalam promosi produk }\end{array}$ \\
\hline Pemasaran & $\begin{array}{l}\text { 2. Perbaikan dan pengembangan kemasan produk gula merah, gula semut, } \\
\text { gula merah cair (sirup aren). }\end{array}$ \\
\hline
\end{tabular}

\section{Hasil}

Untuk bidang produksi pertama yakni peremajaan pohon aren, kelompok pengolah gula merah dari aren menceritakan tentang tindakan mereka yang mulai beralih dari pengolah gula merah dengan mulai menanam kelapa Dalam dan penanaman nilam, karena mereka mengganggap pengolahan gula merah ke depan tidak memiliki prospek yang cerah karena semakin berkurangnya jumlah pohon aren. Akibatnya jumlah pengolah gula aren yang sebelumnya mencapai 20 orang sekarang tinggal 7 orang yang aktif, itu pun sudah berumur lanjut. Hal ini disebabkan anggapan anakan pohon aren yang tumbuh disekitar pohon aren dewasa yang juga tumbuh secara alami adalah anakan yang tumbuh dari akar sebagaimana pada pohon sagu dan Nipa, sehingga ketika pemeliharaan anakan ini dibabat agar pohon yang tumbuh tidak terganggu oleh tunas-tunasnya. Setelah mendapat penyuluhan dan langsung ke lokasi pohon aren yang memiliki anakan bahwa yang tumbuh disekitar pohon aren dewasa adalah anakan dari buah aren, dapat dipisah dan dipindah tanam, respon pengolah gula merah manjadi sangat antusias untuk membudidayakan aren, yang semula hanya mengharapkan yang tumbuh secara liar dan alami. Sikap ini bahkan mendapat dukungan dari Kepala Dusun, Kaur Kesra dan Babinsa setempat. Apalagi setelah mendapat pemaparan tentang pendapatan yang diperoleh jika melakukan budidaya aren dalam 1 ha yang dapat mencapai belasan juta hingga puluhan juta per semesternya. 


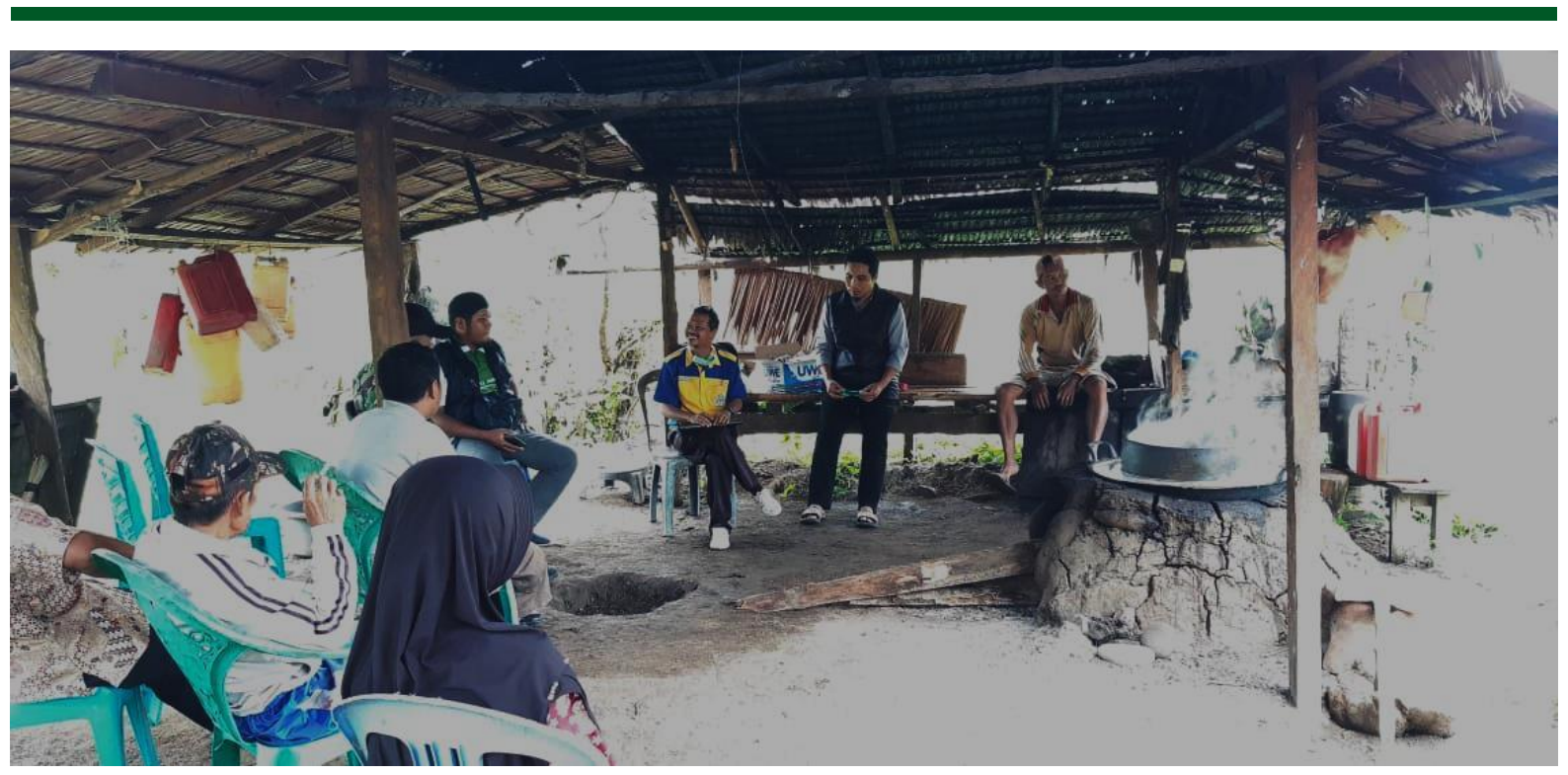

Gambar 3. Pelatihan Produk Pengolahan Aren

Untuk kegiatan bidang produksi kedua yakni penyuluhan pengembangan cetakan gula merah siap jual. Selama ini pembuat gula merah hanya mengenal olahan dalam bentuk cetakan menggunakan tempurung kelapa. Variasi pengolahan yang pernah dilihat adalah gula semut, tetapi pembuat gula merah enggan membuat gula semut dengan alasan ribet dan tidak tahu peruntukannya. Setelah penyuluhan, maka pembuat gula merah mengenal variasi cetakan gula merah yakni cetakan ekonomis, sirup gula merah, gula Kristal. Selain itu pembuat gula merah menjadi mengetahui peruntukkan gula semut dan gula Kristal sebagai bahan baku pembuat minuman instan dengan harga yang lebih tinggi secara ekonomis, terutama sirup gula merah.

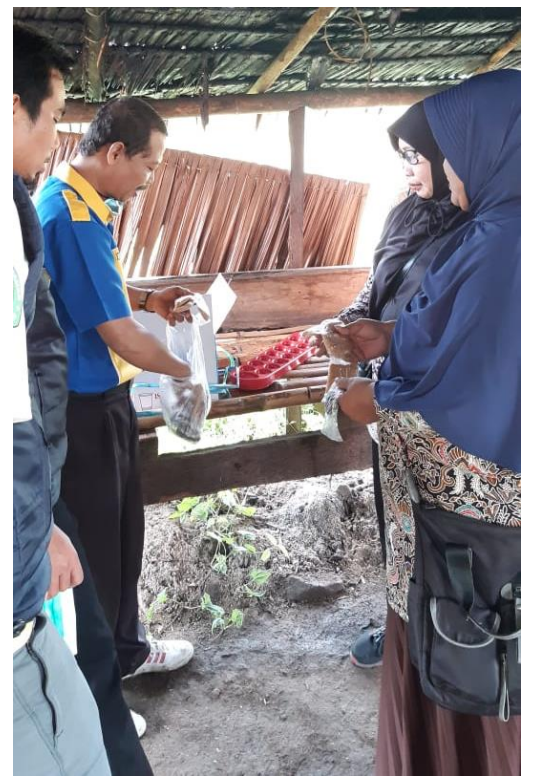

Gambar 4. Menjelaskan Jenis Produk Pengolahan Aren 
Untuk kegiatan bidang manajemen pertama adalah pelatihan pemanfaatan telepon genggam dalam promosi produk, yakni melalui aplikasi Facebook (FB) dan WhattsApp (WA). Penggunaan diajarkan bagaimana bergabung dalam Forum Jual Beli, sedangkan untuk WA diajarkan bagaimana membuat status. Hal ini dilakukan karena pembuat gula merah belum sama sekali memanfaatkan Handpone sebagai sarana untuk promosi produk mereka.

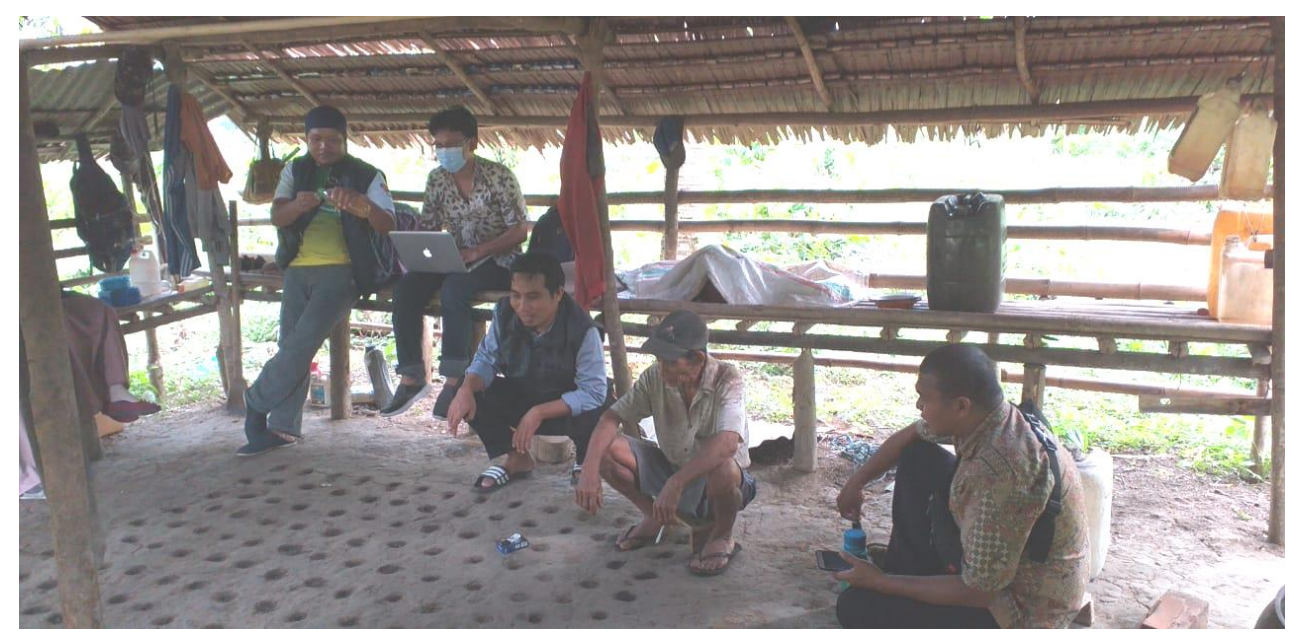

Gambar 5. Pelatihan Promosi dan Pemasaran dengan Media Sosial

Untuk pelatihan kemasan produk gula merah, gula semut dan sirup gula merah dilakukan dengan metode membuat sampel kemasan dan mengenalkan alat pengemas listrik sederhana, karena kemasan yang digunakan adalah plastik gula ukuran $1 \mathrm{~kg}$ yang tipis dan hanya diikat saja pada bagian ujungnya atau dibakar dengan lampu minyak tanah atau lilin. Pengenalan teknik pengemasan sederhana ini diharapkan dapat membuka wawasan pengolah gula merah, sehingga kemasan produknya menjadi lebih menarik.

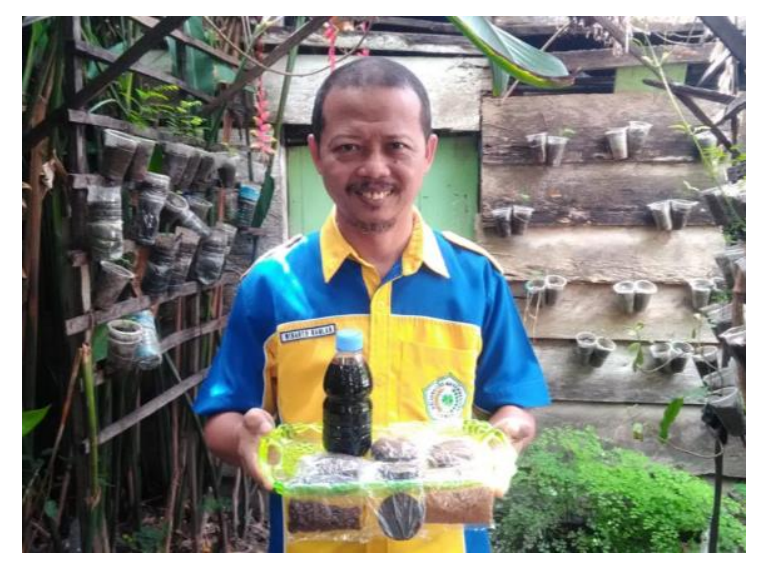

Gambar 6. Ragam Olahan Gula Merah 


\section{Diskusi}

Pada temuan kegiatan PKM Usaha Gula Merah di Desa Moilong yang mengalami penurunan jumlah pengolah gula merah karena faktor kehilngan populasi pohon aren, factor ekonomi dan factor kultural. (Swandewi et al., 2020) menyatakan terdapat 3 faktor yang mempengaruhi secara tradisi pengolah gula aren yakni factor ekonomi, religi dan kultural. Faktor ekonomi menyebabkan pengolah gula merah melakukan pengolahan dan produksi sesuai dengan pesanan tengkulak, sebab telah mengambil uang atau menerima pembayaran didepan. (Maemonah, 2015) melaporkan umumnya pengolah gula aren sudah memiliki pemesanan oleh pengepul, sehingga sulit untuk melakukan pengembangan produk dan juga pasar. Faktor kehilangan populasi pohon aren dan kultural pada pengolah gula aren dipengaruhi oleh pengetahuan dan sikap meneruskan kebiasaan yang sudah ada. (Yuroh \& Maesaroh, 2018) melaporkan factor pendidikan dan pengalaman mempengaruhi produktivitas produksi gula aren. Sehingga diperlukan tindakan penyuluhan dan pendampingan secara berkelanjutan agar pengolah gula aren di Desa Moilong bisa melepaskan diri dari mengambil uang atau pembayaran didepan agar dapat lebih berdaya secara ekonomi, dan tidak terus menerus mengikuti tradisi yang tidak menguntungkan.

\section{Kesimpulan}

Program PKM berhasil memberikan pengetahuan dan pemahaman bagi pengolah gula merah di Desa Moilong Kecamatan Moilong tentang diversifikasi dan pengemasan produk olahan gula merah serta sarana promosi yang mudah dan sesuai pengetahuan dan keterampilan pembuat gula merah.

\section{Daftar Referensi}

Astuti, M., \& Rodiyah, I. (n.d.). Pelatihan Diversifikasi Produk Dalam Meningkatkan Kemandirian Perekonomian Masyarakat Pesisir Product Diversification Training In Improving The Independence Of Coastal Community Economy.

Badan Pusat Statistik. (2020). Kecamatan Moilong Dalam Angka.

Cavestro, L. (2003). PRA-Participatory Rural Appraisal Concepts Methodologies and Techniques. PRA-Participatory Rural Appraisal Concepts Methodologies and Techniques. Web Address: Http://Www. Agraria. Unipd. It/Agraria/Master/CSO203/PARTICIPATORY\% 20RURAL\% 20APPRAISAL., 14(October), 01-07, 14(October), 01-07. 
Goutara, W. S. (1975). Dasar Pengolahan Gula. Departemen Teknologi Hasil Pertanian. Fatemata. IPB. Bogor.

Maemonah, S. (2015). Strategi Pengembangan Industri Kecil Gula Aren Di Kecamatan Limbangan Kabupaten Kendal. 4(4), 414-426.

Mentari, S. N., Djangi, M. J., \& Sudding, S. (2017). Peran Akar Kayu Bayur (Pterospermum sp.) terhadap Fermentasi Nira Aren (Arenga pinnata). Chemica: Jurnal Ilmiah Kimia Dan Pendidikan Kimia, 18(2), 90. https://doi.org/10.35580/chemica.v18i2.5901

Rahim, M. A. (2012). Strategi Pengembangan Usaha Gula Aren Di Desa Sumberharjo Kecamatan Moilong. 2(1), 33-42.

Suharto, E. (2009). Definisi Pemberdayaan Membangun Mayarakat Memberdayakan Rakyat Kajian Strategis Pembangunan Kesejahteraan Sosial \& Pekerjaan Sosial. Bandung: Refika Aditama.

Swandewi, N. P., Mudana, I. W., \& Sendratari, L. P. (2020). Pengetahuan Tradisional Pengolahan Gula Aren Dalam Perspektif Perubahan Sosial Di Desa Pedawa, Buleleng, Bali. 2(1), 105-115.

Yuroh, F., \& Maesaroh, I. (2018). Faktor-Faktor Yang Berpengaruh Terhadap Pendapatan Dan Produktivitas Agroindustri Gula Kelapa Di Kabupaten Pangandaran. 4(2), 254273.

Zainudin, A. (2016). Model Kelembagaan Pemerintahan Desa. JIP (Jurnal Ilmu Pemerintahan): Kajian Ilmu Pemerintahan Dan Politik Daerah, 1(2), 338-351. https://doi.org/10.24905/jip.1.2.2016.338-351 